Maja N. Todorović

Associate Professor University of Belgrade

Faculty of Mechanical Engineering

Milan R. Ristanović

Assistant Professor University of Belgrade

Faculty of Mechanical Engineering

Dragan V. Lazić

Full Professor

University of Belgrade

Faculty of Mechanical Engineering

Radoslav D. Galić

Assistant Lecture University of Belgrade

Faculty of Mechanical Engineering

Tamara S. Bajc

Teaching and Research Associate

University of Belgrade

Faculty of Mechanical Engineering

\section{A Novel Laboratory Set-up for Investigation of Intelligent Automatic Control in Complex HVAC Systems}

This paper presents a new laboratory set-up for the air-conditioning operation analysis in the Laboratory for Automatic Control at the Faculty of Mechanical Engineering, University of Belgrade. The new HVAC laboratory is designed to investigate different complex HVAC system working regimes and to provide desired space comfort. The emphasis is specially given to an impact on energy consumption. The laboratory set-up is designed to operate in the complex, dynamic regimes, when indoor environment parameters are intensively changed, together with a change of outdoor conditions. In order to minimize energy consumption, a new software and various automatic control algorithms are designed for automatic control of the air handlig unit.

Keywords: Laboratory HVAC set-up; Air Handling Unit; Energy Efficiency; Intelligent Automatic Control; Complex Regimes.

\section{INTRODUCTION}

Regarding continuous world energy consumption growth in buildings (around $40 \%$ in developed countries) [1], intelligent automatic controlled HVAC systems are of a great importance for energy savings and optimal comfort conditions in buildings.

This paper presents a new HVAC laboratory set-up for the space air-conditioning in a laboratory at the Faculty of Mechanical Engineering in Belgrade. As a part of the national project TR33047 of the Ministry of Education, Science and Technology of the Republic of Serbia, a new HVAC laboratory is designed and established. The main objective is to verify developed automatic control algorithms and strategies regarding energy consumption reduction, providing the desired space comfort. The system is to operate properly in complex, dynamic regimes, taking into consideration the variation of indoor and outdoor environment parameters changes. In order to minimize energy consumption, a new software is designed for control and supervision of an air handling unit (in further text: AHU). In order to determine heat transfer processes in AHU, appropriate mathematical models are defined for every AHU section and accordingly, different automatic control algorithms are developed.

\section{LABORATORY INSTALATION}

The new laboratory is located in the old building of Faculty of Mechanical Engineering, University of Belgrade. The air-conditioned space consists of a classroom and a mechatronics laboratory within total area of $67.11 \mathrm{~m}^{2}$ and $51 \mathrm{~m}^{2}$ respectively, as well as a research

Received: September 2014, Accepted: December 2014

Correspondence to: Maja Todorovic

Faculty of Mechanical Engineering,

Kraljice Marije 16, 11120 Belgrade 35, Serbia

E-mail: mtodorovic@mas.bg.ac.rs

doi:10.5937/fmet1601065T

(C) Faculty of Mechanical Engineering, Belgrade. Allrights reserved laboratory with total area of $103.8 \mathrm{~m}^{2}$. The height of the laboratory is $7.75 \mathrm{~m}$. In order to provide desired indoor comfort for the classroom and both research labs, a new $\mathrm{AHU}$ is designed. The AHU is designed to eliminate heat loads in summer and to compensate heat losses in transitional periods. In the winter, heat losses are covered with district heating system in a regime $90 / 70^{\circ} \mathrm{C}$. The AHU consists of the following sections: filter, mixing, fan, electrical heater, heat recovery, cooling, adiabatic cooling and water heater section.

With the system, it is possible to test and measure various regimes with variable air flow, using fresh and return air, free cooling, air humidification and dehumidification, in order to determine optimal energy efficient regime and save energy. The following indoor air parameters are possible to measure: indoor air temperature, relative humidity and concentration of $\mathrm{CO}_{2}$. The total volume air flow is $4,000 \mathrm{~m}^{3} / \mathrm{h}$, from which $2,000 \mathrm{~m}^{3} / \mathrm{h}$ supply research lab, while classroom and mechatronics lab are supplied with $1,000 \mathrm{~m}^{3} / \mathrm{h}$ each. The total heat losses are $26.38 \mathrm{~kW}$ and the total heat loads are $14.05 \mathrm{~kW}$.

A water heater section is connected to the district heating system, while an electrical heater is also provided in order to establish optimal comfort conditions for transitional periods and for the frost protection of the heat recovery unit. The cooling section is connected to outdoor refrigerant unit using refrigerant R407C.

There can be found various examples of different technical realizations in air-conditioning systems, [2-4]. The laboratory installation presented in this paper intends to be more than a superset of several typical installations designed for dedicated applications. According to the above mentioned requirements and limitations, appropriate application schematics has been developed (Fig. 1). The company SOKO Inženjering Belgrade has done the physical realization of the AHU (Fig. 2). It is to be noticed that manipulating side of the AHU is made transparent for the purpose of demonstration of the operation phenomena. 


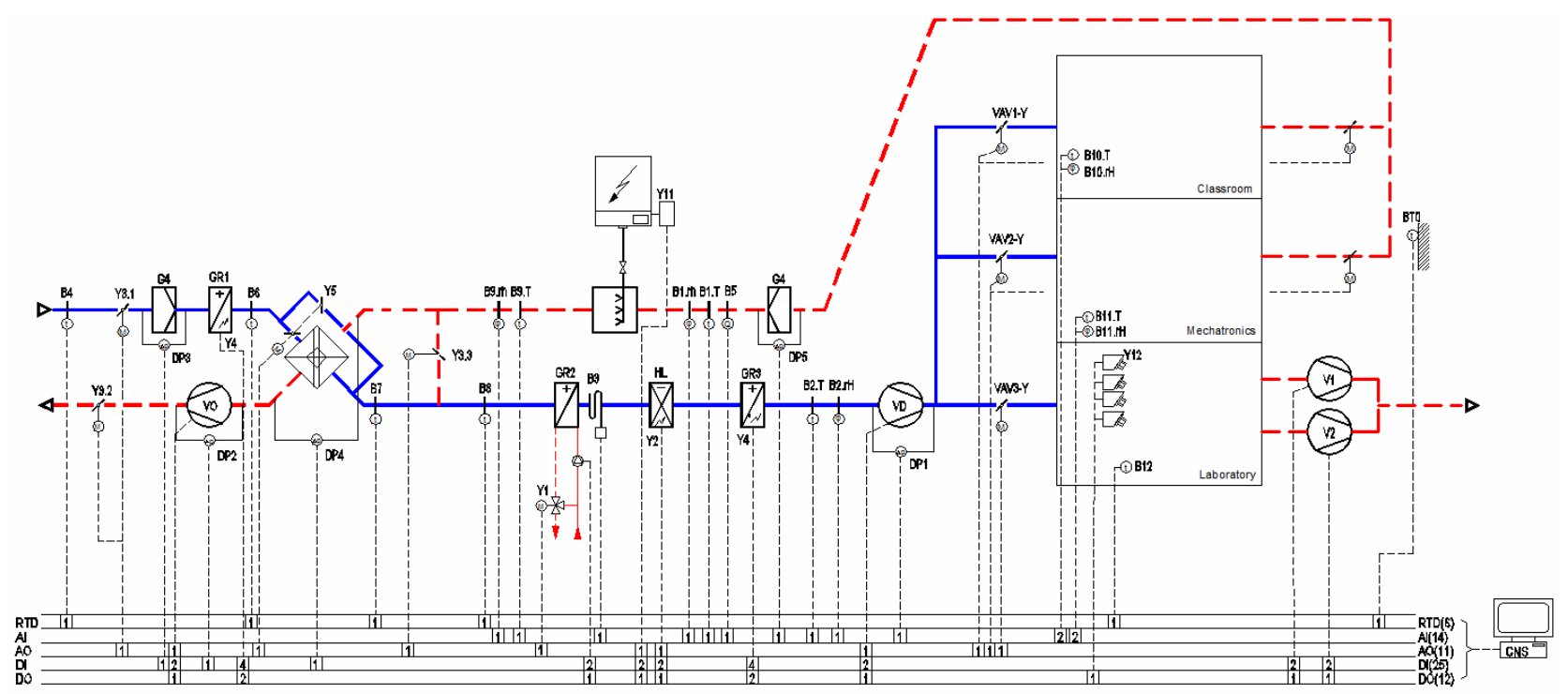

Figure 1. The application automatic control schematic with signals for AHU

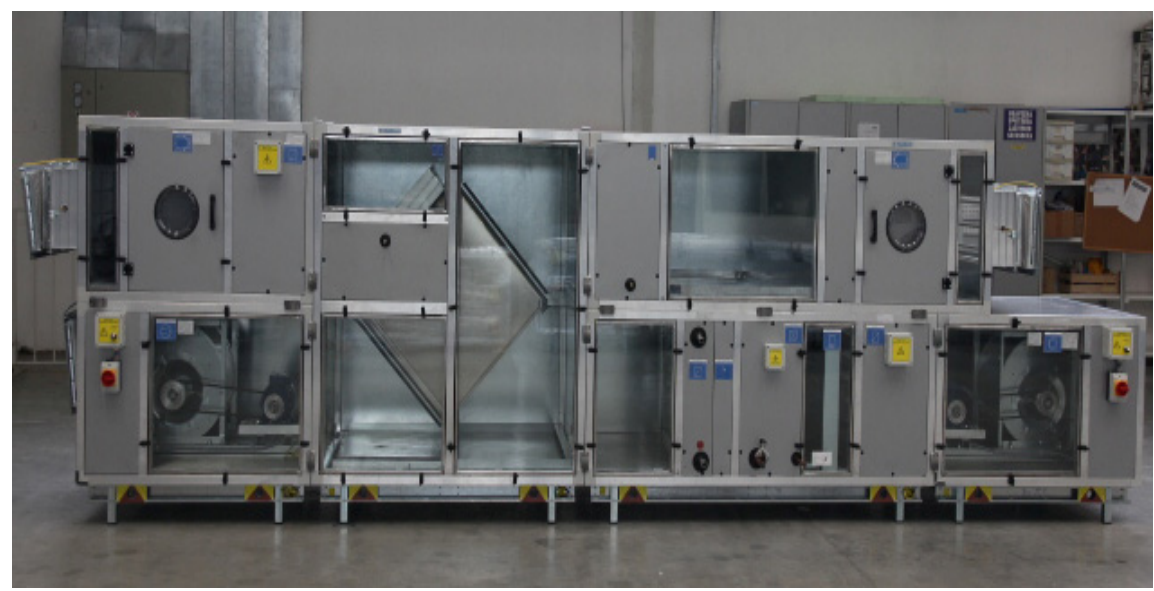

Figure 2. AHU for optimal energy efficient regimes testing - made by Soko Inžinjering Belgrade

\section{MATHEMATICAL MODELING OF DIFFERENT OPERATING REGIMES}

Within the software development phase, a mathematical model for the unsteady state heat transfer regimes has been developed.

A heat flux through the different elements of the building envelope is considered, regarding different building materials. It is assumed that every element is homogeneous part of the construction envelope and that a one-dimensional problem assumption is valid. Unsteady state heat transfer through windows, regarding solar radiation is based upon the ASHRAE calculation method, [5].

The equations are written for heat transfer through building envelope and for the heat exchange in every AHU section as well.

The governing equations for modelling the processes in AHU are written for every element and section. It is assumed that outside temperature is measured for every hour, and being interpolated for desired time step. The indoor air parameters can be sampled in a desirable time step. Regarding that, heat transfer can be observed as a steady-state heat transfer, for each short time step.
Regime 1 - Heating mode: In the heating mode, the amount of the heat transferred through the heat exchanger is given by equation (1):

$$
\Phi_{\mathrm{ht}}=q_{\mathrm{m}, \mathrm{e}} c_{\mathrm{p}, \text { air }}\left(T_{\mathrm{in}, \mathrm{set}}-T_{\mathrm{mix}}\right),
$$

if $T_{\text {in,set }}-T_{\text {mix }}>0$.

Regime 2 - Humidification: If the supply air is humidified, the amount of heat for water evaporation is:

$$
\Phi_{\mathrm{ht}, \mathrm{ev}}=q_{\mathrm{m}, \mathrm{e}} \Delta h_{\mathrm{v}}\left(x_{\mathrm{in}, \mathrm{set}}-x_{\mathrm{HR}}\right),
$$

if $x_{\text {in,set }}>x_{\mathrm{HR}}$.

Regime 3 - Cooling mode: In the cooling mode, the supply air is cooled down to the desired set point temperature and the exchanged amount of heat is:

$$
\Phi_{\mathrm{C}}=q_{\mathrm{m}, \mathrm{e}} c_{\mathrm{p}, \text { air }}\left(T_{\mathrm{in}, \mathrm{set}}-T_{\mathrm{mix}}\right),
$$

if $T_{\text {in,set }}-T_{\text {mix }}<0$.

Regime 4 - Heat recovery: If the cooling process is defined as indirect adiabatic cooling, the return air is cooled down to the minimum wet bulb temperature, by humidification, before entering the heat recovery section. In this case, the adiabatic cooling power is described by following equation: 


$$
\Phi_{\mathrm{C}, \mathrm{AC}}=q_{\mathrm{m}, \mathrm{e}} c_{\mathrm{p}, \mathrm{air}}\left(T_{\mathrm{HD}, \mathrm{AC}}-T_{\mathrm{HD}}\right) .
$$

Sensible heat recovery. The sensible heat recovery efficiency of the heat recovery unit can be calculated as a function of mass flow rate relation between fresh and return air:

$$
\eta_{\text {sens,eff }}=\frac{q_{m, \mathrm{R}}}{q_{m, \mathrm{e}}} \eta_{\mathrm{sens}},
$$

and regarding (5), the temperature after heat exchanger is given by following equation:

$$
T_{\mathrm{HR}}=\eta_{\text {sens,eff }}\left(T_{\mathrm{R}}-T_{\mathrm{e}}\right)+T_{\mathrm{e}} .
$$

Regime 5 - Variable air flow: The total fan power is possible to calculate according to the actual supply and return air flow rates:

$$
\Phi_{\mathrm{el}, \mathrm{fan}}=\Phi_{\mathrm{el}, \mathrm{fan}, \mathrm{sup}}+\Phi_{\mathrm{el}, \mathrm{fan}, \mathrm{ret}}
$$

where the supply and return fans power are given as follows:

$$
\begin{aligned}
& \Phi_{\mathrm{el}, \text { fan,sup }}=\left(\frac{\Delta p_{\mathrm{e}} q_{\mathrm{m}, \mathrm{e}}}{\rho_{\mathrm{air}} \eta_{\mathrm{vent}}}\right) / 1000, \\
& \Phi_{\mathrm{el}, \mathrm{fan}, \mathrm{ret}}=\left(\frac{\Delta p_{\mathrm{R}} q_{\mathrm{m}, \mathrm{R}}}{\rho_{\mathrm{air}} \eta_{\mathrm{vent}}}\right) / 1000 .
\end{aligned}
$$

\section{CONTROL SYSTEM}

Control system for AHU is based on Siemens Simatic S7-300 PLC industrial controller. PLC controller is modular and it is configured to handle all the signals defined by the application schematics in Fig. 1. PLC communicates with a PC for central supervision and control via Profinet communication protocol. A SCADA is developed in the package WinCC.

According to the mathematical model, showed in previous section, and for the transient heat transfer through building envelope as well, the application software for automatic control is developed. The software is designed to track dynamic working regimes of HVAC system in the transient conditions.
The part of the software is designed for air parameter tracking, within the AHU to calculate and compare energy consumption. The user's program is configured in order to vary indicators of energy consumption through various input data. An additional software tool is provided for calculating the primary energy consumption, depending on heating and cooling sources. This is of a great importance for the energy model improvement and introduction of the renewable energy sources (RES) in the future.

The software is designed to operate with hourly weather data, which is of great significance for data acquisition in the case of dynamic system working regimes.

Besides the application software in PLC, the user interface and automatic control algorithm software has also been designed. The user interface is shown in Fig. 3.

The SCADA includes the user management system and the user rights are strictly protected by the user accounts. Figure 4. shows the supervisor's menu for setting the system parameters for AHU.

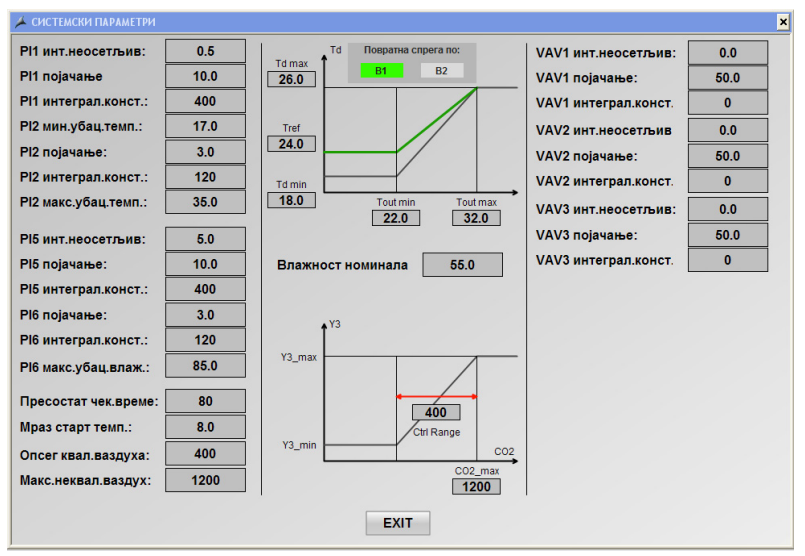

Figure 4. Screen for setting the system parameters for AHU.

Designed system parameters for AHU working regimes are:

- Parameters of the PI controller: There is a various number of controllers: for driving the temperature, for humidity, $\mathrm{CO}_{2}$ and for VAV boxes. The designed control is of cascade type,

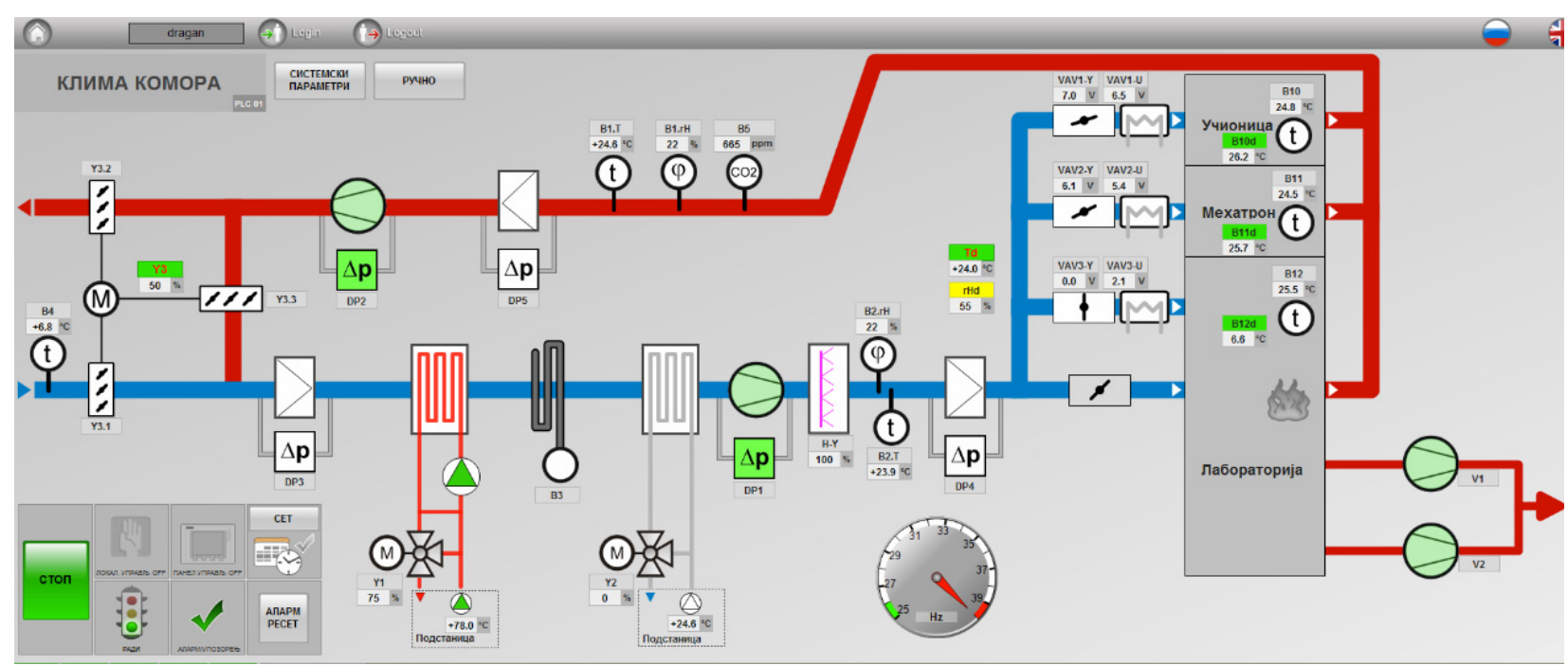

Figure 3. The main screen for central supervisory control of AHU 


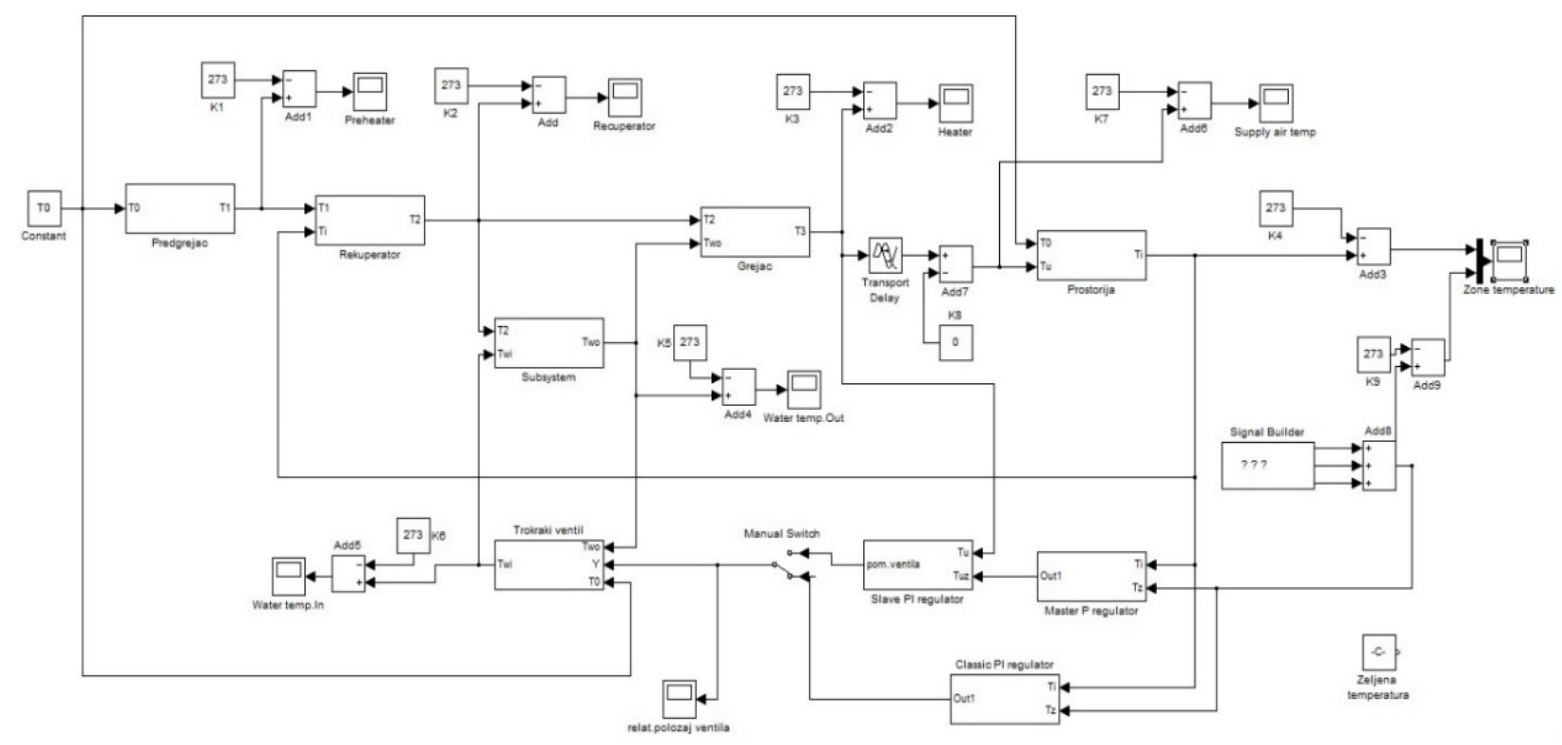

Figure 5. Simulation model of the AHU in heating regime.

driven by temperature sensors B1 and B2, as well as with sequential regulation for fresh air dampers, mixing valves and frequency controlled fan motors.

- Desired indoor temperature value: It is possible to compensate chosen temperature value according to outdoor air temperature. The automatic control can be driven according to the inlet air temperature or to the return air temperature with mechanism for feedback selection.

- Indoor air quality is possible to adjust with various parameters. The control is achieved by driving the dampers for fresh air and changing the velocities of frequency controllers.

\section{NUMERICAL SIMULATION OF HEATING REGIME}

Problem of mathematical modelling of HVAC components and system is extensively treated in the literature. Appropriate mathematical model developed for the heating regime of the above mentioned system is given in [6]. The mathematical model for the classroom includes electrical pre-heater, water heater, heat recovery unit, mixing valve. Based on the mathematical model, a Matlab Simulink simulation model is created (Fig. 5).

Various control techniques are used in contemporary air-conditioning systems, from conventional to modern, [7-8]. However, commercial controllers mainly use cascade PID control algorithm. Cascade control can be used when there are several measurement signals and one control variable. It is particularly useful when there are significant dynamics (e.g. long dead times or long time constants) between the control variable and the process variable. Then, tighter control can be achieved by using an intermediate measured signal that responds faster to the control signal, [9].

Fig. 6 shows comparison of numerical simulation of the conventional PI and cascade P+PI controller for $\mathrm{Kp}=7$ of the $\mathrm{P}$ (master) controller and $0.5 \mathrm{~V} / \mathrm{K}$ and $\mathrm{Ki}$ $=0.01 \mathrm{~V} / \mathrm{s}$ of the PI (slave) controller.

It can be seen that the cascade controller provides considerably better dynamic behaviour of the output, i.e. classroom temperature, compared to the conventional PI controller. Besides, conventional PI controller cannot eliminate oscillations of the classroom temperature in steady state, Fig. 5. In addition, oscillations in valve displacement with conventional PI controller are unacceptable, because it will considerably reduce life cycle of the actuator. On the other hand, $\mathrm{P}+\mathrm{PI}$ controller provides smooth valve displacement, Fig. 6.

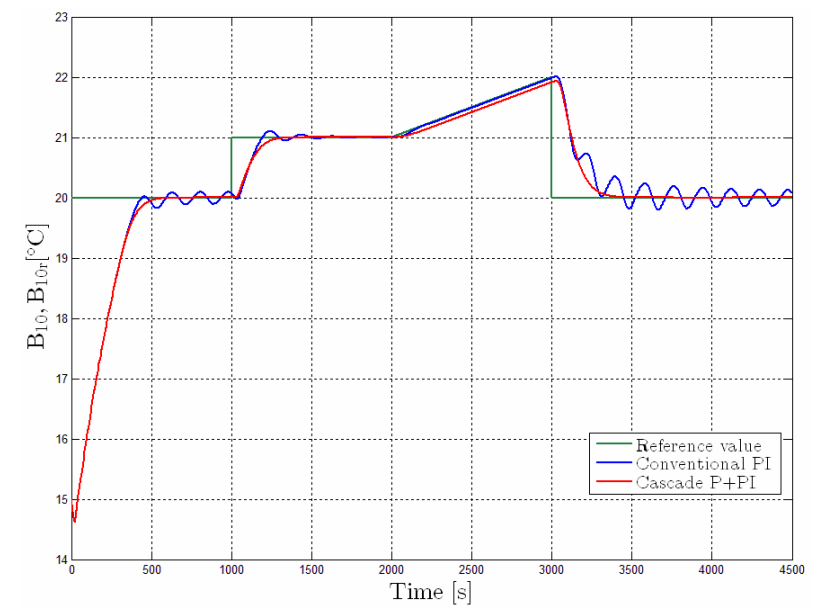

Figure 6. Time response of the classroom temperature.

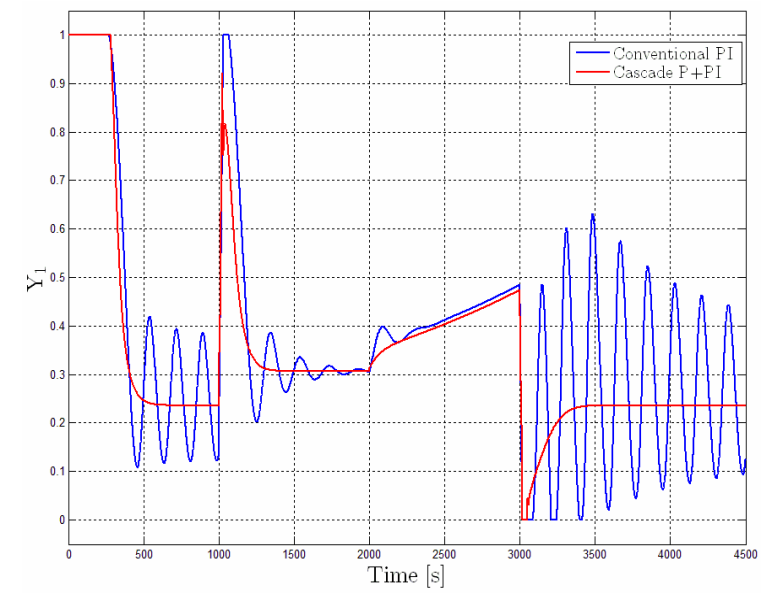

Figure 7. Control signal on heater mixing valve. 


\section{CONCLUSIONS}

The new laboratory facility presented in this paper has a very important contribution to establishing the optimal working regimes for $\mathrm{AHU}$, providing the best solution according to the energy consumption. The presented automatic control system is crucial for enabling dynamic settings, control and logging of indoor air parameters temperature, humidity and $\mathrm{CO}_{2}$ concentration, in a desired period of time. This system provides continuous energy consumption control and monitoring in the most efficient way. Development of mathematical and simulation models provide the opportunity of analyses of dynamic behaviour by using different control algorithms and for optimisation of existing control algorithms and parameters. In addition, it is a powerful tool for investigation of new control algorithms. The established laboratory set-up shall be used in the future for carrying out various real-time tests and measurements, as well as comparison to the numerical simulations.

\section{ACKNOWLEDGMENT}

This paper has been done as a result of the national project TR33047 supported by the Ministry of Education, Science and Technology of Republic of Serbia for period 2011-2014.

\section{REFERENCES}

[1] Todorović, N. M., Bajc, S.T.: The influence of building working regimes on total building energy consumption, Termotehnika, Vol. 38, No. 2, pp. 109-119, 2012.

[2] Goli, D.: Automation of air-conditioning devices, SMEITS, Beograd, 1989. (in Serbian)

[3] Bach, H, et. al.: Regelungstechnik in der Versongungstechnik, 3. Auflage, Verlag C.F. Mueller, Karlsruhe, 1992.

[4] Control of ventilation and air conditioning plants: http://www.buildingtechnologies.siemens.com/

[5] Todorović, N. M.: The Air-Conditioning Energy Savings Achieved by Application of Timepredicted Driven Night Ventilation, FME Transactions, Vol. 42, No. 2, 2014. pp. 161-166

[6] Mandić, P., Babić, I., Stojanović, S., Ristanović, M., Lazić D.: Modeling, simulation and control of winter regime of an air conditioning system in a classroom, Proceedings of the $44^{\text {th }}$ International HVAC Congress, Belgrade, December 4-6., 2013, pp. 135-143.(in Serbian)

[7] Legweel Khaled M.B., Lazić Dragan V., Ristanović Milan R., Lozanović-Šajić Jasmina V., The performance of pip-cascade controller in HVAC system, Thermal Science 2014, Volume 18, Issue suppl.1, pp. 213-220

[8] HosseinMirinejad, Karla Conn Welch, Lucas Spicer:A Review of Intelligent Control Techniques in HVAC Systems, Energytech, 2012 IEEE, 29-31 May 2012, Clivlend, OH, pp. 1-5

[9] Shengwei Wang, Intellingent Buildings and Building Automation, Spon Press, New York, NY, 2010.

\section{NOMENCLATURE}

\begin{tabular}{|c|c|}
\hline$c_{\mathrm{p}, \text { air }}$ & $\begin{array}{l}\text { specific heat capacity of air at constant } \\
\text { preassure }[\mathrm{kJ} / \mathrm{kgK}]\end{array}$ \\
\hline$q_{\mathrm{m}, \mathrm{e}}$ & mass flow rate of a fresh air $[\mathrm{kg} / \mathrm{h}]$ \\
\hline$q_{m, \mathrm{R}}$ & mass flow rate of a return air $[\mathrm{kg} / \mathrm{h}]$ \\
\hline$\eta_{\text {sens,eff }}$ & sensible heat recovery efficiency [-] \\
\hline$\eta_{\text {sens }}$ & $\begin{array}{l}\text { nominal sensible efficiency of a heat } \\
\text { recovery [-] }\end{array}$ \\
\hline$\eta_{\text {vent }}$ & overall efficiency of a fan [-] \\
\hline$T_{\mathrm{HD}, \mathrm{AC}}$ & $\begin{array}{l}\text { temperature after heat recovery with } \\
\text { adiabatic cooling }\left[{ }^{\circ} \mathrm{C}\right]\end{array}$ \\
\hline$T_{\mathrm{HD}}$ & $\begin{array}{l}\text { temperature after heat recovery without } \\
\text { adiabatic cooling }\left[{ }^{\circ} \mathrm{C}\right]\end{array}$ \\
\hline$T_{\mathrm{HR}}$ & temperature after heat recovery $\left[{ }^{\circ} \mathrm{C}\right]$ \\
\hline$T_{\text {in,set }}$ & supply air set point temperature $\left[{ }^{\circ} \mathrm{C}\right]$ \\
\hline$T_{\operatorname{mix}}$ & temperature of a mixed air $\left[{ }^{\circ} \mathrm{C}\right]$ \\
\hline$T_{\mathrm{e}}$ & temperature of a fresh air $\left[{ }^{\circ} \mathrm{C}\right]$ \\
\hline$T_{\mathrm{R}}$ & temperature of a return air $\left[{ }^{\circ} \mathrm{C}\right]$ \\
\hline$\Delta h_{\mathrm{V}}$ & enthalpy of water evaporation $[\mathrm{kJ} / \mathrm{kg}]$ \\
\hline$x_{\text {in,set }}$ & $\begin{array}{l}\text { absolute water content in supply air - set } \\
\text { point }[\mathrm{kg} / \mathrm{kg}]\end{array}$ \\
\hline$x_{\mathrm{HR}}$ & $\begin{array}{l}\text { absolute water content in fresh air after heat } \\
\text { recovery }[\mathrm{kg} / \mathrm{kg}]\end{array}$ \\
\hline$\Delta p_{\mathrm{e}}$ & pressure drop for supply fan $[\mathrm{Pa}]$ \\
\hline$\Delta p_{\mathrm{R}}$ & pressure drop for return fan $[\mathrm{Pa}]$ \\
\hline$\Phi_{\mathrm{ht}}$ & $\begin{array}{l}\text { the amount of the heat transferred through } \\
\text { the heat exchanger [W] }\end{array}$ \\
\hline$\Phi_{\mathrm{ht}, \mathrm{ev}}$ & $\begin{array}{l}\text { the amount of heat for water evaporation } \\
\text { [W] }\end{array}$ \\
\hline$\Phi_{\mathrm{C}}$ & the amount of heat for cooling [W] \\
\hline$\Phi_{\mathrm{C}, \mathrm{AC}}$ & the adiabatic cooling power [W] \\
\hline$\Phi_{\mathrm{el}, \mathrm{fan}}$ & the total fan power [W] \\
\hline$\Phi_{\text {el,fan,sup }}$ & the actual supply air flow rate [W] \\
\hline$\Phi_{\text {el,fan,ret }}$ & the actual return air flow rate [W] \\
\hline
\end{tabular}

\section{Greek symbols}

$\begin{array}{ll}\rho & \text { density }\left[\mathrm{kg} / \mathrm{m}^{3}\right] \\ \eta & \text { efficiency [- }]\end{array}$

\section{НОВО ЛАБОРАТОРИЈСКО ПОСТРОЈЕЊЕ ЗА ИСПИТИВАЊЕ ИНТЕЛИГЕНТНОГ АУТОМАТСКОГ УПРАВЉАҢА У КОМПЛЕКСНИМ КГХ СИСТЕМИМА}

Маја Н. Тодоровић, Милан Р. Ристановић, Драган В. Лазић, Радослав Д. Галић, Тамара С. Бајц

У раду је приказано ново лабораторијско посторојење за анализу рада климатизационог система, које је смештено у Лабораторији за аутоматско управљање на Машинском факултету Универзитета у Београду. Нова КГХ лабораторија je пројектована у циљу испитивања различитих 
сложених режима рада, уз обезбеђење жељених услова комфора. Посебан акценат је стављен на утицај режима рада на потрошњу енергије. Лабораторијско постројење је пројектовано да ради у сложеним динамичким условима, када се унутрашњи и спољни параметри средине знатно мењају током времена. У циљу минимизовања потрошње енергије развијени су нови управљачки софтвери и различити алгоритми управљања клима коморе. 